\author{
JURNAL ABDIMAS P-ISSN 2615-6849, E-ISSN 2622-3686

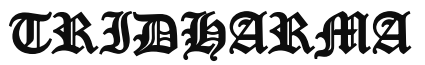 \\ Jurnal ABDIMAS Vol. 2,No. 2, April 2021 Hal (61-67)

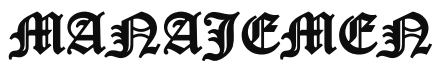 \\ @ Prodi Manajemen Fakultas Ekonomi Universitas Pamulang \\ Email: abdimasjurnal.unpam@gmail.com Telp: (021) 741-2566
}

\title{
PELATIHAN BAHAYA NARKOBA DAN KENAKALAN REMAJA TERHADAP MANAJEMEN KEUANGAN
}

\author{
Evita Vibriana*, Setyanto*, Endang Nurita*, Ninik Anggraeni*, Ahmad Akbar* \\ Dosen Fakultas Ekonomi Universitas Pamulang \\ Email*: dosen01602@unpam.ac.id; dosen01600@unpam.ac.id; \\ dosen01972@unpam.ac.id; dosen00976@unpam.ac.id; dosen01973unpam.ac.id
}

\begin{abstract}
ABSTRAK
Menurut UU No. 22 Tahun 1997, Narkotika adalah "zat atau obat yang berasal dari tanaman atau bukan tanaman baik sintesis maupun semi sintesis yang dapat menyebabkan penurunan atau perubahan kesadaran, hilangnya rasa, mengurangi sampai menghilangkan rasa nyeri, dan dapat menimbulkan ketergantungan". Sebenarnya Narkoba adalah obat legal yang digunakan dalam dunia kedokteran, namun dewasa ini Narkoba banyak disalahgunakan. Bahkan di kalangan remaja tidak sedikit yang terjerumus dalam bahaya narkoba. Banyak dari mereka yang menggunakan Narkoba dengan alasan untuk Upaya pemberantasan Narkoba pun sudah sering dilakukan, namun masih sedikit kemungkinan untuk menghindarkan Narkoba dari kalangan remaja maupun dewasa. Hingga saat ini upaya yang paling efektif untuk mencegah pengaruh Narkoba pada remaja yaitu dari pendidikan, keluarga. Orangtua diharapkan mengawasi dan mendidik anaknya untuk selalu menjauhi narkoba. Dan hingga kini narkoba pun telah merajalela di kalangan para remaja. Hal tersebut akan mengganggu prestasi belajar siswa yang mengkonsumsi Narkoba tersebut. Jika para remaja khususnya usia sekolah mengkonsumsi Narkoba tanpa henti (ketagihan) akan merusak beberapa jaringan di tubuh pecandu yang mengakibatkan tidak konsentrasi dalam pelajaran, selalu gelisah, tidak fokus pada pelajaran sehingga prestasi siswa pecandu akan menurun. Jika banyak remaja yang banyak mengkonsumsi narkoba dan banyak pula remaja yang sekolah akan kehilangan prestasi belajarnya.
\end{abstract}

Kenakalan remaja adalah pelampiasan masalah yang dihadapi oleh kalangan remaja yang tindakannya menyimpang. Menurut ahli sosiologi Kartono, Kenakalan Remaja atau dalam bahasa Inggris dikenal dengan istilah juvenile delinquency merupakan gejala patologis sosial pada remaja yang disebabkan oleh satu bentuk pengabaian sosial. Akibatnya mereka mengembangkan bentuk perilaku yang menyimpang. Sedangkan menurut Santrock "Kenakalan remaja merupakan kumpulan dari berbagai perilaku remaja yang tidak dapat diterima secara sosial hingga terjadi tindakan kriminal."

Dengan adanya kenakalan remaja maka akan berpengaruh terhadap keuangan pribadi seseorang. Kesuksesan financial seseorang ditentukan oleh perilaku keuangan inividu itu sendiri. Tentunya banyak faktor yang mempengaruhi perilaku manajemen keuangan. Dalam teori perilaku terencana berasumsi bahwa perilaku seseorang dipengaruhi oleh sikap dan 


\title{
JURNAL ABDIMAS P-ISSN 2615-6849, E-ISSN 2622-3686

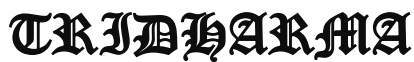

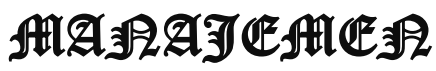

norma lain yang dipengaruhi oleh faktor eksternal, contohnya pengalaman, tingkat literasi dan pengetahuan seseorang.

Perilaku manajemen keuangan adalah "kemampuan seseorang dalam mengatur (perencanaan, penganggaran, pemeriksaan, pengelolaan, pengendalian, pencarian dan penyimpanan) dana keuangan sehari-hari. Munculnya perilaku financial management, merupakan dampak dari besarnya hasrat seseorang untuk memenuhi kebutuhan hidupnya sesuai dengan tingkat pendapatan yang diperoleh" (Al Kholilah \& Iramani, 2013).

Dalam program kegiatan Pengabdian Kepada Masyarakat (PKM) kali ini sasarannya adalah para santriwan santriwati di yayasan Alkamilah dengan memberikan pengetahuan mengenai bahaya narkoba. Lembaga pendidikan diharapkan juga mampu mendidik mereka untuk menjadi generasi bebas narkoba dan kenakalan remaja khususnya para santri.

Berdasarkan permasalahan yang dihadapi anggota Yayasan Alkamilah, Bojongsari, Depok, melalui kegiatan pengabdian kepada masyarakat (PKM) para dosen dan mahasiswa dari Universitas Pamulang mencoba membantu memberikan pelatihan-pelatihan yang dibutuhkan Yayasan Alkamilah untuk para anak didiknya. Diharapkan dengan pelatihan bahaya narkoba dan kenakalan remaja terhadap manajemen keuangan ini dapat membantu menambah ilmu pengetahuan, meningkatkan wawasan para santri di yayasan tersebut.

\section{Kata kunci: Narkoba, Kenakalan Remaja, Manajemen Keuangan}

\begin{abstract}
According to Law no. 22 of 1997, Narcotics are "substances or drugs derived from plants or non-plants, both synthesis and semi-synthesis, which can cause a decrease or change in consciousness, loss of taste, reduce to eliminate pain, and can cause dependence". Actually, drugs are legal drugs that are used in the world of medicine, but nowadays drugs are being misused. Even among teenagers, not a few are falling into the dangers of drugs. Many of them who use drugs for reasons of drug eradication efforts have often been done, but there is still little possibility to avoid drugs among adolescents and adults. Until now, the most effective efforts to prevent the influence of drugs on adolescents are from education, family. Parents are expected to supervise and educate their children to stay away from drugs. And until now, drugs have been rampant among teenagers. This will interfere with the learning achievement of students who consume these drugs. If adolescents, especially school-age children, consume drugs without stopping (addiction) it will damage several tissues in the addict's body resulting in not concentrating in lessons, always being anxious, not focusing on lessons so that the student addict's achievement will decrease. If many adolescents consume a lot of drugs and many teenagers go to school, they will lose their learning achievement.

Juvenile delinquency is an outlet for problems faced by adolescents whose actions deviate. According to the sociologist Kartono, juvenile delinquency or in English known as juvenile delinquency is a social pathological symptom in adolescents caused by a form of social neglect. As a result they develop deviant forms of behavior. Meanwhile, according to Santrock "juvenile delinquency is a collection of various adolescent behaviors that are socially unacceptable to the point of criminal action."

With juvenile delinquency it will affect one's personal finances. A person's financial success is determined by the individual's own financial behavior. Of course, many factors influence financial management behavior. In the theory of planned behavior it assumes that a person's
\end{abstract}




\section{JURNAL ABDIMAS P-ISSN 2615-6849, E-ISSN 2622-3686

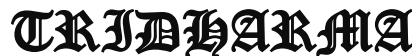 AIA \\ Email: abdimasjurnal.unpam@gmail.com Telp: (021) 741-2566}

behavior is influenced by attitudes and other norms that are influenced by external factors, for example experience, a person's level of literacy and knowledge.

Financial management behavior is "a person's ability to manage (planning, budgeting, checking, managing, controlling, searching and storing) daily financial funds. The emergence of financial management behavior is the impact of a person's desire to meet their needs in accordance with the level of income earned "(Al Kholilah \& Iramani, 2013).

In the Community Service program (PKM) this time the target is santriwan santriwati at the Alkamilah foundation by providing knowledge about the dangers of drugs. Educational institutions are also expected to be able to educate them to become a generation free of drugs and juvenile delinquency, especially students.

Based on the problems faced by members of the Alkamilah Foundation, Bojongsari, Depok, through community service activities (PKM) lecturers and students from Pamulang University have tried to help provide the training needed by the Alkamilah Foundation for their students. It is hoped that the training on the dangers of drugs and juvenile delinquency on financial management can help increase knowledge, increase the insight of the students at the foundation.

\section{Keywords: drugs, juvenile delinquency, financial management}

\section{PENDAHULUAN}

Di Indonesia, pencandu narkoba ini perkembangannya semakin pesat. Para pencandu narkoba itu pada umumnya berusia antara 11(sebelas) sampai 24 (dua puluh empat) tahun. Artinya usia tersebut ialah usia produktif atau usia pelajar. Pada awalnya, pelajar yang mengonsumsi narkoba biasanya diawali dengan perkenalannya dengan rokok. Karena kebiasaan merokok ini sepertinya sudah menjadi hal yang wajar di kalangan pelajar saat ini. Dari kebiasaan inilah, pergaulan terus meningkat, apalagi ketika pelajar tersebut bergabung ke dalam lingkungan orang-orang yang sudah menjadi pencandu narkoba. Awalnya mencoba, lalu kemudian mengalami ketergantungan. Dalam kurun waktu dua dasawarsa terakhir ini Indonesia telah menjadi salah satu negara yang dijadikan pasar utama dari jaringan sindikat peredaran narkotika yang berdimensi internasional untuk tujuan-tujuan komersial.
Untuk jaringan peredaran narkotika di negara-negara Asia, Indonesia diperhitungakan sebagai pasar (marketstate) yang paling prospektif secara komersial bagi sindikat internasional yang beroperasi di negara-negara sedang berkembang. Remaja yang seharusnya menjadi kader-kader penerus bangsa kini tidak bisa lagi menjadi jaminan untuk kemajuan Bangsa dan Negara. Bahkan perilaku mereka cenderung merosot.

Masa remaja adalah masa dimana seorang manusia sedang berada dalam pencarian jati dirinya, ingin mengenal siapa dirinya sebenarnya. Seorang manusia dikatakan remaja, jika sudah menginjak usia 17 (Tujuh Belas) tahun. Dan dalam usia ini, seorang manusia mengalami masa yang dinamakan masa pubertas. Saat pubertas, biasanya manusia ingin mencoba segala suatu yang baru dalam hidupnya, muncul berbagai macam gejolak emosi, dan banyak timbul masalah baik dalam keluarga maupun lingkungan sosialnya. 


\section{JURNAL ABDIMAS P-ISSN 2615-6849, E-ISSN 2622-3686

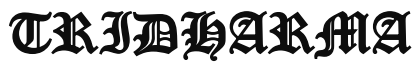 \\ Jurnal ABDIMAS Vol. 2,No. 2, April 2021 Hal (61-67) \\ AtA: \\ @ Prodi Manajemen Fakultas Ekonomi Universitas Pamulang}

Email: abdimasjurnal.unpam@gmail.com Telp: (021) 741-2566

\begin{abstract}
Bentuk kenakalan remaja banyak sekali, antara lain : Narkoba, free sex, tawuran, pergaulan bebas, dan lainlain. Kenakalan remaja kebanyakan dilakukan oleh mereka yang gagal dalam mengembangkan emosi jiwanya, mereka tidak bisa menahan diri terhadap hal-hal baru yang masuk ke dalam dirinya, yang menimbulkan sikap yang tidak seharusnya dilakukan. Kenakalan remaja adalah wujud dari konflik yang tidak terselesaikan dengan baik pada masa kanak-kanak maupun pada saat remaja.
\end{abstract}

Yayasan Al-Kamilah adalah Yayasan yatim piatu dan dhuafa yang didirikan oleh Ustad Ahmad Badruddin. Dapat menampung didalam asrama sebanyak 30 (Tiga Puluh) anak asuh dari Jabotabek. Sedangkan untuk keseluruhan yang berada di luar mencapai 50 (Lima Puluh) anak. Sehingga total yang diasuh yayasannya mencapai 80 (Delapan Puluh) anak dari Jabodetabek, maupun Kebumen, Purwakarta, Banten dan lainnya. Pernah dikunjungi oleh 33 (Tiga Puluh Tiga) Negara. Serta banyak prestasi yang telah diraihnya seperti juara pertama keteladanan seJawa barat. Sehingga menjadi kebanggaan kota Depok karena kerap mengukir prestasi gemilang dikancah provinsi maupun nasional.

Kami selain dosen Prodi Akuntansi Universitas Pamulang juga berperan dalam masyarakat melalui kegiatan Pengabdian Kepada Masyarakat (PKM), melalui pelatihan bahaya narkoba dan kenakalan remaja sejak usia dini di Yayasan Alkamilah agar terhindar dari narkoba dan kenakalan remaja serta bagaimana mengatur keuangan yang baik. 3.Memberikan motivasi dengan memberikan contoh agar terhindar dari narkoba

\section{TINJAUAN PUSTAKA}

\section{Pengertian Narkoba}

Narkoba adalah singkatan dari narkotika dan obat-obatan terlarang. Sementara nafza merupakan singkatan dari narkotika, alkohol, dan zat adiktif lainnya (obat-obat terlarang, berbahaya yang mengakibatkan seseorang mempunyai ketergantungan terhadap obatobat tersebut). Kedua istilah tersebut sering digunakan untuk istilah yang sama, meskipun istilah nafza lebih luas lingkupnya. Narkotika berasal dari tiga jenis tanaman, yaitu (1) candu, (2) ganja, dan (3) koka. Ketergantungan obat dapat diartikan sebagai keadaan yang mendorong seseorang untuk mengonsumsi obat-obat terlarang secara berulang-ulang atau berkesinambungan. Apabila tidak melakukannya dia merasa ketagihan (sakau) yang mengakibatkan perasaan tidak nyaman bahkan perasaan sakit yang sangat pada tubuh (Yusuf, 2004: 34).

Narkotika adalah zat atau obat yang berasal dari tanaman atau bukan tanaman, baik sintetis maupun semi sintetis yang dapat menyebabkan penurunan atau perubahan kesadaran, hilangnya rasa nyeri dan dapat menimbulkan ketergantungan (Undang-Undang No. 22 tahun 1997). Narkotika adalah zat atau obat yang berasal dari tanaman atau bukan tanaman, baik sintetis maupun semi sintetis yang dapat menyebabkan penurunan atau perubahan kesadaran, hilangnya rasa nyeri dan dapat menimbulkan ketergantungan (Undang-Undang No. 35 tahun 2009). Narkotika digolongkan menjadi tiga golongan sebagaimana tertuang dalam lampiran 1 undang-undang tersebut. Yang termasuk jenis narkotika adalah:

Tanaman papaver, opium mentah, opium masak (candu, jicing, jicingko), opium obat, morfina, kokaina, ekgonina, tanaman ganja, dan damar ganja. 


\section{JURNAL ABDIMAS P-ISSN 2615-6849, E-ISSN 2622-3686

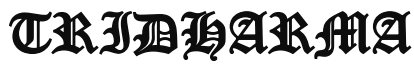 \\ Jurnal ABDIMAS Vol. 2,No. 2, April 2021 Hal (61-67)

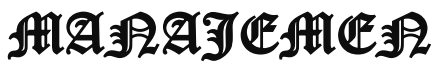 \\ @ Prodi Manajemen Fakultas Ekonomi Universitas Pamulang}

Email: abdimasjurnal.unpam@gmail.com Telp: (021) 741-2566

Garam-garam dan turunan-turunan dari morfina dan kokaina, serta campurancampuran dan sediaan-sediaan yang mengandung bahan tersebut di atas.

Psikotropika adalah zat atau obat, baik alamiah maupun sintetis bukan narkotika, yang berkhasiat psikoaktif melalui pengaruh selektif pada susunan saraf pusat yang menyebabkan perubahan pada aktivitas mental dan perilaku (Undang-Undang No. 5/1997). Terdapat empat golongan psikotropika menurut undang-undang tersebut, namun setelah diundangkannya UU No. 35 tahun 2009 tentang narkotika, maka psikotropika golongan I dan II dimasukkan ke dalam golongan narkotika. Dengan demikian saat ini apabila bicara masalah psikotropika hanya menyangkut psikotropika golongan III dan IV sesuai Undang-Undang No. 5/1997. Zat yang termasuk psikotropika antara lain: Sedatin (Pil BK), Rohypnol, Magadon, Valium, Mandrax, Amfetamine, Fensiklidin, Metakualon, Metifenidat, Fenobarbital, Flunitrazepam, Ekstasi, Shabu-shabu, LSD (Lycergic Syntetic Diethylamide) dan sebagainya. Bahan Adiktif berbahaya lainnya adalah bahanbahan alamiah, semi sintetis maupun sintetis yang dapat dipakai sebagai pengganti morfina atau kokaina yang dapat mengganggu sistem syaraf pusat, seperti: Alkohol yang mengandung ethyl etanol, inhalen/sniffing (bahan pelarut) berupa zat organik (karbon) yang menghasilkan efek yang sama dengan yang dihasilkan oleh minuman yang beralkohol atau obat anaestetik jika aromanya dihisap.

Contoh: lem/perekat, aceton, ether dan sebagainya.

Masa remaja merupakan suatu fase perkembangan antara masa anak-anak dan masa dewasa. Perkembangan seseorang dalam masa anak-anak dan remaja akan membentuk perkembangan diri orang tersebut di masa dewasa. Karena itulah bila masa anak-anak dan remaja rusak karena narkoba, maka suram atau bahkan hancurlah masa depannya.

Pada masa remaja, justru keinginan untuk mencoba-coba, mengikuti trend dan gaya hidup, serta bersenang-senang besar sekali. Walaupun semua kecenderungan itu wajar-wajar saja, tetapi hal itu bisa juga memudahkan remaja untuk terdorong menyalahgunakan narkoba. Data menunjukkan bahwa jumlah pengguna narkoba yang paling banyak adalah kelompok usia remaja.

Masalah menjadi lebih gawat lagi bila karena penggunaan narkoba, para remaja tertular dan menularkan HIV/AIDS di kalangan remaja. Hal ini telah terbukti dari pemakaian narkoba melalui jarum suntik secara bergantian. Bangsa ini akan kehilangan remaja yang sangat banyak akibat penyalahgunaan narkoba dan merebaknya HIV/AIDS. Kehilangan remaja sama dengan kehilangan sumber daya manusia bagi bangsa.

Penyalahgunaan narkotika dan obatobatan terlarang di kalangan generasi muda dewasa ini kian meningkat Maraknya penyimpangan perilaku generasi muda tersebut, dapat membahayakan keberlangsungan hidup bangsa ini di kemudian hari. Karena pemuda sebagai generasi yang diharapkan menjadi penerus bangsa, semakin hari semakin rapuh digerogoti zat-zat adiktif penghancur syaraf. Sehingga pemuda tersebut tidak dapat berpikir jernih. Akibatnya, generasi harapan bangsa yang tangguh dan cerdas hanya akan tinggal kenangan.Sasaran dari penyebaran narkoba ini adalah kaum muda atau remaja. Kalau dirata-ratakan, usia sasaran 


\section{JURNAL ABDIMAS P-ISSN 2615-6849, E-ISSN 2622-3686

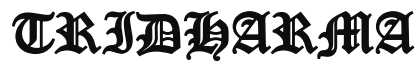 \\ Jurnal ABDIMAS Vol. 2,No. 2, April 2021 Hal (61-67)

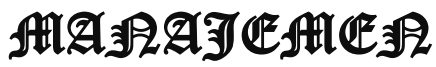 \\ @ Prodi Manajemen Fakultas Ekonomi Universitas Pamulang}

Email: abdimasjurnal.unpam@gmail.com Telp: (021) 741-2566

narkoba ini adalah usia pelajar, yaitu berkisar umur 11 sampai 24 tahun. Hal tersebut mengindikasikan bahwa bahaya narkoba sewaktu-waktu dapat mengincar anak didik kita kapan saja.

\section{METODE PELAKSANAAN}

Dalam pelaksanaan kegiatan ini metode yang kita ambil adalah dengan metode ceramah, diskusi dan Tanya jawab. Pada sesi ceramah membahas mengenai bahaya narkoba dan kekalan remaja memperoleh laba dimana dalam prosedurnya dapat membentuk sesuatu yang produktif dan mempunyai faedah lebih. Wirausahawan atau seseorang wirausaha juga harus mempunyai perilaku yang khusus dan menyatu pada diri sendiri misalnya keyakinan diri, sehingga bisa mendirikan seseorang untuk mempunyai keinginan lebih untuk mencari akal sesuatu yang lebih dahulu belum sempat dijalankan. Selanjutnya gambaran bagaimana menjadi seorang pengusaha atau entrepreneur untuk memotivasi para santri kedepannya berwirausaha. Dengan berwirausaha mereka yang akan menciptakan dan membuka lapangan kerja di masyarakat. Wirausaha adalah sebagai bagian utama dari soko guru perekonomian Indonesia dan mengurangi jumlah pengangguran serta pada kesempatan tersebut juga disebutkan bahwa berwirausaha memupuk jiwa kemandirian bagi masyarakat. Pada sesi diskusi, para santri diberikan pemahaman tentang teori tentang bisnis syariah, yaitu bisnis yang dilakukan sesuai ajaran agama Islam. Program pelatihan yang didukung oleh para dosen akuntansi dan dosen manajemen Universitas Pamulang. Pada sesi tanya jawab, membahas bagaimana mencari peluangpeluang bisnis yang ada diluaran sesuai kenyataan dimasyarakat dengan mengikuti perkembangan jaman seperti bisnis online saat ini yang sedang berkembang pesat serta memberikan contoh orang-orang muda yang sukses saat ini dengan berwirausaha di Indonesia.

\section{PRA KEGIATAN}

Sebelum acara Pengabdian Masyarakat dilakukan tim Dosen Pengabdian Kepada Masyarakat UNPAM melakukan beberapa agenda antara lain dapat digambarkan dalam alur berikut:

1. Tahap Persiapan

a.Kegiatan Observasi dan Perizinan

Observasi dilakukan dengan melakukan survey pada lokasi yang akan dijadikan kegiatan Pengabdian Kepada Masyarakat (PKM) yakni di Yayasan Alkamilah Depok. Survey dilakukan 3 (Tiga) kali untuk menentukan titik yang tepat yang akan dijadikan sebagai point kegiatan. Dalam tahapan perizinan para dosen berkordinasi dengan pihak terkait, seperti: pimpinan Yayasan Alkamilah dan pengurus Yayasan tersebut.

b.Penyusunan RAB

Rencana Anggaran dan Belanja dipersiapkan dalam hal pembelian belanja bahan seperti: Honor narasumber, cinderamata atau plakat, konsumsi, sertifikat, materi, pembuatan jurnal dan door prize serta beberapa peralatan lain nya yaitu: tempat pelatihan, sound system, laptop dan LCD proyektor.

c.Pengajuan Proposal

Proposal kegiatan PKM diajukan pada tanggal 11 Nopember 2020 dan setelah melalui proses review, disetujui oleh Ketua LPPM Bapak Ali Madinsyah pada tanggal 16 Nopember 2020.

Tahap Implementasi pelaksanaan kegiatan Pengabdian Kepada Masyarakat (PKM) dilaksanakan di Ruangan pertemuan Yayasan Alkamilah Depok pada tanggal 26,27 dan 28 Nopember 2020

METODE PELAKSANAAN

Dalam pelaksanaan kegiatan ini metode 


\section{JURNAL ABDIMAS P-ISSN 2615-6849, E-ISSN 2622-3686

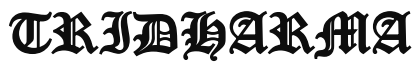 \\ Jurnal ABDIMAS Vol. 2,No. 2, April 2021 Hal (61-67)

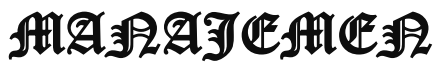 \\ @ Prodi Manajemen Fakultas Ekonomi Universitas Pamulang}

Email: abdimasjurnal.unpam@gmail.com Telp: (021) 741-2566

yang kita ambil adalah dengan metode ceramah, diskusi dan Tanya jawab. Pada sesi ceramah membahas mengenai Wirausaha ialah seseorang yang menjalankan suatu usaha untuk memperoleh laba dimana dalam prosedurnya dapat membentuk sesuatu yang produktif dan mempunyai faedah lebih. Wirausahawan atau seseorang wirausaha juga harus mempunyai perilaku yang khusus dan menyatu pada diri sendiri misalnya keyakinan diri, sehingga bisa mendirikan seseorang untuk mempunyai keinginan lebih untuk mencari akal sesuatu yang lebih dahulu belum sempat dijalankan. Selanjutnya gambaran bagaimana menjadi seorang pengusaha atau entrepreneur untuk memotivasi para santri kedepannya berwirausaha. Dengan berwirausaha mereka yang akan menciptakan dan membuka lapangan kerja di masyarakat. Wirausaha adalah sebagai bagian utama dari soko guru perekonomian Indonesia dan mengurangi jumlah pengangguran serta pada kesempatan tersebut juga disebutkan bahwa berwirausaha memupuk jiwa kemandirian bagi masyarakat. Pada sesi diskusi, para santri diberikan pemahaman tentang teori tentang bisnis syariah, yaitu bisnis yang dilakukan sesuai ajaran agama Islam. Program pelatihan yang didukung oleh para dosen akuntansi dan dosen manajemen Universitas Pamulang. Pada sesi tanya jawab, membahas mengenai bahaya narkoba dan kenakalan remaja terhadap manajemen keuangan.

\section{HASIL DAN PEMBAHASAN}

Hasil yang telah dicapai
berdasarkan
pelaksanaan Pengabdian Kepada Masyarakat (PKM) yang telah dilaksanakan dapat identifikasi sebagai berikut:

1.Acara dibuka dengan Pembukaan PKM Dengan pembacaan Ummul AlQuran bersama sama, dimana pada saat ini diberikan berbagai macam sambutan, baik dari pihak Yayasan Alkamilah maupun dari pihak UNPAM. Setelah itu, acara dilanjutkan didalam ruangan dengan memberikan pembekalan materi kepada para peserta PKM yang terdiri dari para guru yayasan dan Santriwan Santriwati Yayasan Al-Kamilah Depok Jawa Barat.

2.Materi yang pertama diberikan oleh narasumber adalah tentang Pengaruh Bahaya Narkoba dan Kenakalan Remaja Terhadap Manajemen Keuangan, Yaitu pengetahuan tentang pemahaman Narkoba, kenakalan remaja dan manajemen keuangan Para Santri diberikan motivasi menjadi pribadi yang baik dan mental yang kuat dimasyarakat tidak mudah terpengaruh terhadap lingkungan yang tidak baik sehingga menjadi sosok generasi yang selalu optimis menatap masa depan.

3.Setelah semua materi disampaikan, maka dilakukan Tanya jawab seputar bahaya narkoba, kenakalan remaja dan manajemen keuangan melalui quis dan permainanpermainan dengan memberikan pertanyaan pertanyaan dengan memberikan hadiah kuis baik yang bertanya maupun yang menjawab. Tujuannya adalah untuk menguji pemahaman peserta mengenai materi yang sudah diberikan.

\section{KESIMPULAN DAN SARAN Kesimpulan}

Kegiatan pelaksanaan Pengabdian

Kepada Masyarakat (PKM) Kepada Santriwan Santriwati disebuah yayasan sangat dibutuhkan, dengan memberikan Pelatihan Binis Syariah wawasan Santri bertambah luas untuk bekal masa depan mereka.

Pengabdian Masyarakat selanjutnya melaksanakan pendampingan kepada santriwan santriwati dalam rangka mewujudkan santri yang mandiri, dengan 


\section{JURNAL ABDIMAS P-ISSN 2615-6849, E-ISSN 2622-3686

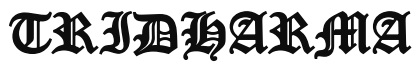 \\ Jurnal ABDIMAS Vol. 2,No. 2, April 2021 Hal (61-67)

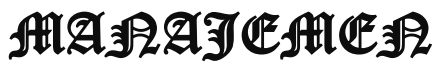 \\ @Prodi Manajemen Fakultas Ekonomi Universitas Pamulang}

Email: abdimasjurnal.unpam@gmail.com Telp: (021) 741-2566

memberikan materi-materi pelatihan lainnya yang dibutuhkan.

Kegiatan PKM ini telah memberikan kontribusi kepada para Santri dengan memberikan bisnis syariah itu dan nantinya diterapkan. Berdasarkan pelaksanaan kegiatan Pengabdian Kepada Masyarakat yang dilaksanakan di Yayasan Alkamilah, Bojongsari, Sawangan, Depok pada hari Sabtu, Minggu dan Senin, Tanggal 26,27 dan 28 Juni 2020, dapat ditarik kesimpulan bahwa secara umum kegiatan pengabdian kepada masyarakat dapat terlaksana dengan baik dan mendapat sambutan dan dukungan dari pihak Yayasan Alkamilah dari segi tempat, sarana prasarana dan akomodasi, serta antusias para peserta yaitu Santriwan Satriwati sehingga dapat bermanfaat bagi mereka untuk masa depannya.

\section{Saran}

Berdasarkan kegiatan yang sudah terlaksana beberapa saran yang dapat kami sampaikan kedepannya adalah kami peserta Pengabdian Masyarakat (PKM), karena pesertanya adalah para santri dengan usia masih muda perlu kedepannya adalah pembinaan kearah karakter dan moral supaya menjadi pribadi yang kuat dengan tidak terpengaruh pergaulan-pergaulan tidak baik diluaran, yaitu perlu diberikan materi tentang bahaya narkotika dan kenakalan remaja, serta kerjasama dengan yayasan agar dapat mewujudkan perpustakaan dengan mengumpulkan buku-buku bekas dan baru untuk santriwan santriwati untuk bisa lebih mudah mengakses pengetahuan lebih banyak dan dapat diterapkan dalam kehidupan sehari-hari.

\section{DAFTAR PUSTAKA}

Iswandi dan Saiful Amiq, 2013, "Manajemen Keuangan Keluarga"
Artikel Online https://juraganmakalah.blogspot.com/2 013/03/manajemen-keuangankeluarga-i.html (Diakses Hari Selasa 6 Oktober 2020)

Kasmir (2010), Pengantar Manajemen Keuangan. Edisi Kedua, Penerbit: Kencana Prenada Media Group, Jakarta.

Love Life Daily, 2020, "Manajemen Keuangan bagi Lajang dan Keluarga Baru di Era New Normal" Artikel Onlinehttps://ilovelife.co.id/blog/mana jemen-keuangan-bagi-lajang-dankeluarga-baru-di-era-new-normal/. (Diakses Hari Selasa 6 Oktober 2020).

Gitman, Lawrence, J.(2015). Principles of Manajerial Finance. International Edition, 10th edition, Pearson Education, Baston.

Hasibuan, Malayu S.P. (2012). Manajemen Sumber Daya Manusia. Jakarta : PT.Bumi Aksra.

Pasaribu, V. L. D., Susanti, F., \& Hartuti, E. T. K. (2019). Memotivasi Siswa dan Siswi SMK Letris Indonesia di Dalam Menentukan Pilihan Untuk Melanjutkan Pendidikan Atau Bekerja Setelah Lulus Sekolah. Jurnal Pengabdian Dharma Laksana, 1(2), 161-172.

Pasaribu, V. L. D., Agrasadya, A., Shabrina, N., \& Krisnaldy, K. (2020). MENJADI ENTERPRENEUR MUDA YANG MEMILIKI JIWA LEADERSHIP UNTUK MENGHADAPI MASA DEPAN. Abdi Laksana, 1(1).

Pasaribu, V. L. D., Elburdah, R. P., Sudarso, E., \& Fauziah, G. (2020). PENGGUNAAN MANAJEMEN WAKTU TERHADAP PENINGKATAN PRESTASI BELAJAR DI SMP ARAISIYAH. Jurnal ABDIMAS Tri Dharma Manajemen, 1(1). 


\section{JURNAL ABDIMAS P-ISSN 2615-6849, E-ISSN 2622-3686

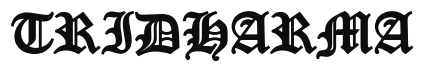 \\ Jurnal ABDIMAS Vol. 2,No. 2, April 2021 Hal (61-67)

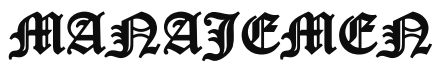 \\ @Prodi Manajemen Fakultas Ekonomi Universitas Pamulang}

Email: abdimasjurnal.unpam@gmail.com Telp: (021) 741-2566

Pasaribu, V. L. D., Sulaiman, S., Sutiman, S., Thaharudin, T., \& Purnomo, B. Y. (2020). PENGENALAN LETAK POSYANDU TERDEKAT DIKELURAHAN PISANGAN DENGAN MANAJEMEN PEMASARAN REVOLUSI 4.0 UNTUK MENINGKATKAN PENGETAHUAN MASYARAKAT LETAK DAN FUNGSI POSYANDU TERDEKAT PADA KELURAHAN PISANGAN. DEDIKASI PKM, 1(1), 105-110.

Pasaribu, V. L. D., Oktrima, B., Prabowo, B., Arianto, N., \& Haryoko, U. B. (2020). PROGAM PENDAMPINGAN DAN PENYELENGGARAAN PENDIDIKAN ANAK PADA USIA DINI TERHADAP PRESTASI BELAJAR DILINGKUNGAN RT 020 RW 009. KEL GIRI PENI. KEC WATES. YOGYAKARTA. JURNAL LOKABMAS KREATIF, 1(1), 71-75.

https://www.kompasiana.com/irmalistiani ngrum/58fdfe58c223bd8755fa3b58/kenak alan-remaja-dan-dampaknya-bagikemajuan-bangsa. https://republika.co.id/berita/pptp01328/ma najemen-keuangan-bagi-milenial-1

http://etheses.uinmalang.ac.id/2253/5/08410087 Bab 2.pdf http://journal.unpad.ac.id/prosiding/article /viewFile/14393/6947

\section{FOTO KEGIATAN}

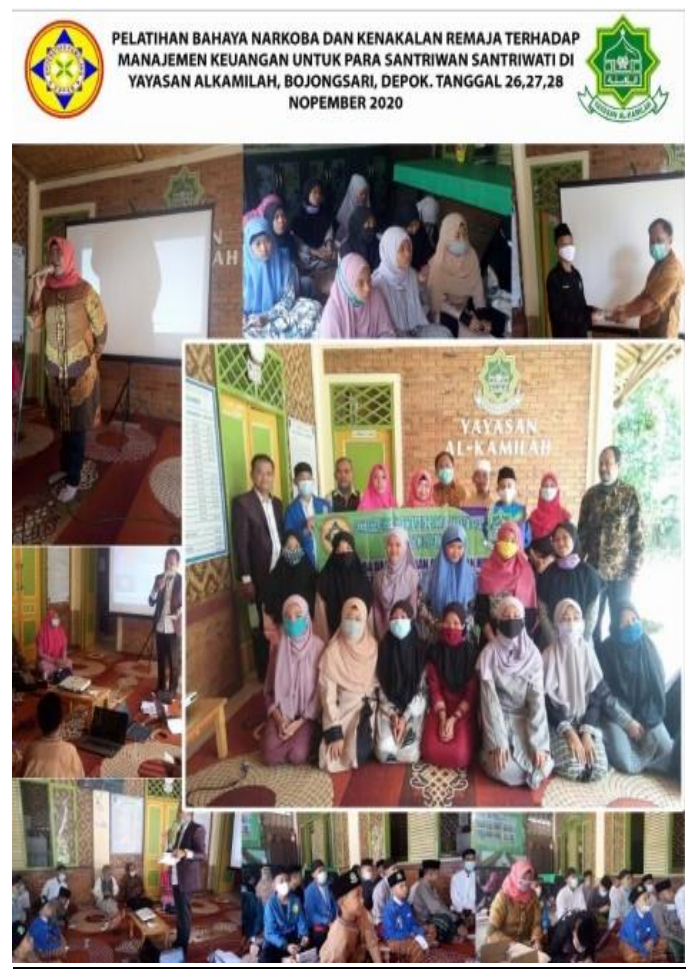

